Academy of Management Proceedings

proceedings.aom.org

doi: 10.5465/AMBPP.2015.17267abstract

ACAD MANAGE PROC January 20152015 (Meeting Abstract Supplement) 17267

Organizations \& the Natural Environment

\title{
The Role of Sustainable Entrepreneurs within Sustainable Energy Action Plans
}

\author{
Federica Gasbarro \\ Eleonora Annunziata \\ Francesco Rizzi \\ Marco Frey \\ + Author Affiliations
}

\begin{abstract}
Sustainable entrepreneurs are assumed to have a catalytic role in sustainable development, new ventures in the early stages and incumbent firms in the following stages. However, some studies argue that such radical shifts are unlikely to succeed without parallel political actions. This is particularly suiting in the case of energy sector and the transition to a low- carbon economy through renewable energy. Therefore, another stream of literature suggests to study sustainable entrepreneurship in a wider context with encompasses socio-ecological system. Then, there can be rooms for policy influencing new sustainable ventures with the aim of developing sustainable corporate cultures from the outset. Our study on the role of sustainable entrepreneurs within Sustainable Energy Action Plans show that incumbents firms are engaged in sustainable development in early stages as well as new ventures and that there is a mutual interplay between sustainable entrepreneurs and public institutions towards sustainable development. In other words either firms have an active role in triggering transition to sustainable development (i.e. institutional push) or are beneficiaries of public policies aimed at reshaping the local context towards sustainable development (institutional pull).
\end{abstract}

Low carbon economy Sustainable entrepreneurship Transition management

Copyright of Academy of Management Journal is the property of Academy of Management and its content may not be copied or emailed to multiple sites or posted to a listserv without the copyright holder's express written permission. However, users may print, download, or email articles for individual use. 